\title{
Visiting Ground Zero
}

\section{Sacred echoes in secular rites}

For the past several years since September 11, 2001, large numbers of people from across the continent and around the world have visited the site of the devastated World Trade Center in New York. Scholars in religious studies and the social sciences have noticed that there were and continue to be (though less so over time) religious aspects to the observances and performances of visitors to 'Ground Zero', as the site of the former World Trade Center almost immediately came to be called. (See, e.g., Grimes 2006a.) A central argument of this article is that the ongoing stream of visitors to Ground Zero, strictly speaking, does not qualify this phenomenon as a pilgrimage in the traditional religious sense; it is more akin to the growing phenomenon of religious tourism, ${ }^{1}$ although it is not exactly that either. Nonetheless the event of 9/11 generated many ritualized activities; the article will also address the process scholars call 'ritualization' and related terms in ritual studies. Although ritualized performances at Ground Zero do not amount to a pilgrimage in the narrow sense that historians of religion mean when they analyze traditional pilgrimages, such as the Hajj to Mecca, or following the Via Dolorosa in Jerusalem, visiting Ground Zero has taken on both secular and religious elements which will be discussed below.

The ritual performances at Ground Zero and pertaining to the memorializing of 9/11 are better understood in terms of an emerging field of scholarship called 'disaster ritual'. Standing in silence, annual memorials, planning a lasting monument to honour the victims, are all characteristics of the phenomena termed disaster ritual behaviour. In Disaster Ritual: Explorations of an Emerging Ritual Repertoire, Ron Grimes and others analyze the traces of Christian-liturgical, general religious and profane-secular elements in several case studies that incorporate coalescences of disaster and ritual, such as street

1 Religious tourism, also called 'faith tourism', can be broadly defined as (usually organized) travel to religious sites. The religious aspect focuses on the site(s) visited and not necessarily on the intentions or experiences of the visitors. See Kamil 2000. 
riots, the Estonia ferryboat disaster in the Baltic Sea in 1994, and the World Trade Center in 2001 (Post et al. 2003). ${ }^{2}$ This approach, however, will not overlook the aspects of modern secular and religious pilgrimage associated with visiting Ground Zero.

In this article I will address the following aspects: (1) Even before midmorning on September 11, the nineteen young men who carried out the attack engaged in rites of mental, spiritual and bodily preparation; their rituals began before Ground Zero became a pilgrimage site. Survivors of the attack also engaged in ritual behaviour. (2) Many of the families and friends of those who perished at Ground Zero got as close as they could to the devastation in a desperate search for missing loved ones, leaving photos and mementos at the site, not unlike remembrances and requests left at religious shrines and gravesites. (3) Thousands of city workers and volunteers spent months at Ground Zero looking for human remains and removing the wreckage. Their part, too, had ritual elements. (4) Entrepreneurs very quickly appeared selling souvenirs and kitsch related to the World Trade Center and the 9/11 disaster. (5) Politicians and public officials made well publicized trips in order to be seen and heard at Ground Zero. That, too, was a form of national civil religion, and accordingly a nondenominational God was invoked in public ceremonies. As soon as the streets adjacent to the site of the devastated Twin Towers were cleared and declared safe, visitors from across America and around the world went to Ground Zero and continue to go, to reflect on the colossal absence in silent awe.

I will begin on a personal note by recalling my own experience of $9 / 11$ as an educator of university students and professor of Islamic Studies, and I will discuss what I call the 'culture of 9/11' as it has evolved, especially in America. ${ }^{3}$ Next I will offer definitions of ritual and cognate terms, such as 'rites', 'ritualizing', and the like. Then I want to reflect on the documents left behind by several of the suicide bombers, to understand both their unique religious character as well as their ritual elements. Following that I will turn on 15 October 2009). At the 'Pilgrimage Today' conference at the Donner Institute, Turku, Finland (August 19-21, 2009), it was pointed out by Prof. William S. Sax of the University of Heidelberg, that the American reaction to September 11 and its aftermath was more intense than reactions in Europe and Asia, a point that I readily concede. In what follows, I will focus on the significance of $9 / 11$ and Ground Zero for Americans in general. 
to other elements of ritual suggested above-by survivors, workers, visitors to Ground Zero and public figures who exhibited ritualized behaviour.

\section{Preliminaries and personal observations}

I write about these matters not as a specialist in ritual studies. As a historian of religion I am familiar with theories of ritual and ritual studies, particularly in the Muslim world. I have written about Islamic rituals and pilgrimage for encyclopaedias and in my general textbook on Islam (Martin 1996). However, the focus of my scholarly work is not on ritual studies per se. This article springs from a slightly different academic background. For several years I have been particularly concerned with what impact the attack on the World Trade Center on September 11, 2001 has had, or should have had, on my work as an educator and writer, as well as on the students I teach. I will dilate on this point briefly.

In America, by September 12, 2001, many of us were asking: Did 9/11 irrevocably change the world we live in and how we live in it? Was it a tipping point in modern history? Was it perverse evidence that Samuel Huntington's declaration in a famous 1993 article of a 'Clash of Civilizations' had become a self-fulfilling prophecy, and as neo-conservative politicians in Washington have warned ever since? ${ }^{4}$ Has it changed the way we define religion and do religious studies? What is my moral obligation as a scholar of Islam in the face of growing public hostility toward Islam and Muslims by some church leaders, politicians, and those, such as Geert Wilders 5 in Holland and David Horowitz ${ }^{6}$ in America, who foment hate and mistrust of all Muslims? In response to the Islamophobic discourse coming from the religious and political right in America and Europe, the majority of Islam specialists (most of them non-Muslims themselves) have turned more and more to writing and public speaking in defence of Islam and Muslims. Does our academic obliga-

4 Huntington 1993: 22-49. The article and the quick and sizeable reaction to it was followed by Huntington's book-length rejoinder, The Clash of Civilizations and the Remaking of World Order (1996). Akeel Bilgrami argued the case for the 'Clash of Civilizations' could become a self-fulfilling prophecy following September 11 if public policy experts relied on Huntington's shallow understanding of global cultures were relied upon. See Bilgrami’s perceptive essay, 'The Clash Within Civilizations' (2003: esp. 88 f.).

5 Geert Wilders's blog is: http://www.geertwilders.nl/.

6 David Horowitz's blog is: http://frontpagemag.com/. It is linked to Robert Spencer's notorious Jihad Watch: http://www.jihadwatch.org/. 
tion to conduct unbiased research ever coincide with our moral obligation to speak out against untruths, even if that amounts to presuming to speak 'for' Muslims in their defense?

In 1799 Friedrich Schleiermacher published his famous defence of Christianity at the dawn of the Enlightenment, titled Über die Religion: Reden an die Gebildeten unter ihren Verächtern (in English: On Christianity: Speeches to Its Cultured Despisers, published in 1994). Since the Iranian Revolution in 1979, and especially since 2001, many scholars of Islamic studies, in perhaps an unconscious reflex on Schleiermacher, are openly engaged in a project that might be called: 'On Islam: Replies to Its Cultured [and Uncultured] Despisers.' Schleiermacher was, of course, a famous Lutheran pastor and theologian. The new defenders of Islam (of which I have admittedly but cautiously become one) are often non-Muslim scholars teaching in secular and public universities. To put this differently, if scholars in religious studies in America made the defence of Christianity their chief concern, they would rightly be criticized by their colleagues in philosophy, history, and the social sciences, for violating the academic mission of the modern university - they would be accused of doing theology rather than Religionswissenschaft, the academic study of religion. Are we skating on thin ice when our scholarly mission becomes devoted to defending a religious tradition from its critics, even when the critique of that religion is vicious and unfounded? This question entails a discussion of ethics in contemporary scholarship which lies outside the scope of this essay, but which I take up in forthcoming book on Muslims and secularism.

\section{The culture of $9 / 11$}

Various kinds of evidence point to the pivotal significance of $9 / 11$ at the beginning of the twenty-first century. Exhibit A: The emotional impact of 9/11 on students. Every year since 2001 I have taught courses on religion and conflict that have tried to deal with these questions. Each class of students has reacted powerfully and emotionally to images and discussions of 9/11. On the morning of September 11, as the planes were attacking the Twin Towers, I was teaching a class of about forty students, some of whose parents and neighbours worked on Wall Street near the World Trade Center. Class time was a crisis time in several ways: some students were understandably fearful for parents and relatives who worked in or near the World Trade Center and left class to try to reach them by cell phone (in vain, given the destruction of towers and relays at the World Trade Center); some were fearful the attacks 
might not be over; some were angry and spoke passionately of the need for revenge. An attempt to hold a constructive dialogue gave way to dismissing the class in order to find out more about what was happening. I decided then and ever since that the best way to examine the meaning of September 11 and Ground Zero was to begin classes on Religion and Violence by asking students to talk about their experience of $9 / 11$, to tell their story.

In the first few school terms after 2001, most students were able to narrate their own personal experience on that September 11, although often with emotion (they, too, were in class that Tuesday morning). As the years have passed, the students in my classes each year were younger and younger in 2001; as younger students at the time, they reported being confused about what they thought was happening on 9/11; often teachers, administrators and parents tried to shield them from the nature of it when it first happened. In the spring of 2009 I showed the documentary 'Faith and Doubt at Ground Zero' to my Introduction to Religion class. Most of the students had been in middle school in 2001-ages 11-13. Several of them were moved to tears or rendered speechless by the video images in the documentary and the personal narratives of persons who experienced 9/11 directly in NYC. ${ }^{7}$ Raw fears, even when they are diminished by the passage of time, can still be evoked in many young people in America by images and video footage of $9 / 11$ and its aftermath.

If we turn our attention to literature and public discourse, I offer as 'Exhibit B' that 9/11 and the events that took place at Ground Zero are deeply embedded in what especially North American scholars of religion teach and write about. Three or four years ago I began to notice a curious fact as I was trying to keep up with journal articles and new books in Islamic and religious studies published each year. Virtually every book and article on Islam and even more generally on religion or other religions-published in America in 2002 and after-cited September 11, 2001 in the opening paragraph of the introduction. ${ }^{8}$ Reference to $9 / 11$ became a necessary incipient raison d'être to introduce the study of religion in the twenty-first century. This of course has been less true in Europe. However, coming to terms with 9/11 has not been entirely absent in works by European, Middle Eastern and Asian scholars. There is

7 A 2002 two-hour documentary produced by Frontline for Public Broadcasting System, directed by Helen Whitney. http://www.pbs.org/wgbh/pages/frontline/shows/ faith/ (last viewed on 20 October 2009).

8 Recent works published in Europe and the Muslim world less frequently feature mention of the destruction of the World Trade Center as a factor that bears upon writing about religion in the twenty-first century. 
some, perhaps postmodern, sense in which, when we now talk about religion, or indeed the contemporary world more generally, we are talking about a political, social and cultural environment that has different cultural and political DNA from the world in which North American scholars of religion did their scholarly work during the last decades of the twentieth century.

Finally, let me offer as 'Exhibit C', reference to 9/11 in popular fictionnovels and short stories - that have appeared since 2002. Much of twenty-first century fiction by authors from South and West Asia is about cross-cultural and multicultural conflicts-Indians, Pakistanis, Arabs and others trying to make the transition from traditional life in the old country to modern life in the new world. Fiction by Western authors, Americans in particular, written in the same period, frequently incorporate the episode of September 11, 2001 and its aftermath into their narratives. Artists are often able to probe more deeply into the psychological effects of events than scholars normally attempt to do, by putting the discourse in first- or third-person narrative, where feelings, conflicting emotions, and moral dilemmas emerge to reveal the human dimension of a story. My first encounter with a fictional reference to 9/11 was in British novelist Nicholas Mosley's surrealistic tale, Inventing God (2003). The title is a reference to Voltaire's famous dictum: 'If God did not exist it would be necessary to invent him.' The novel ends with an oblique reference to September 11 in New York, which is left hanging as to what it meant and what is next-much as were, perhaps, many people globally. The action is set mostly in the Middle East-where God was, if not invented, he was at least claimed by each of the Abrahamic religions-Judaism, Christianity and Islam-as its own. The narrative-often disjointedly describing what the characters are perceiving and understanding to be and take place in phenomenal reality-follows Jewish, Christian, Muslim, secular and mystical players. At one point in the narrative, one the main protagonists, Dario, is musing over some recent entries in his diary that telegraph and comment on the vague reference to the disaster of $9 / 11$ at the end of the novel:

Towards the end of the twentieth century when it was realized that many of the old certainties and ideals were blowing away and people were groping after them like children with gas balloons gone on the wind-

-no more communion, no more fascism, no more God as an old retainer in the sky whom one could tell what to tell one to do-

- towers built up towards heaven coming crashing down, and each person talking, talking, complaining in a different language and putting the blame on others-. (Mosley 2003: 168.) 
For Mosley, as for many Christian writers, struggling with the relevance of religion in post-Enlightenment Europe, the destruction of the Twin Towers was a reflex on the fall of the Tower of Babel, the symbol of human arrogance and hübris.

In a somewhat different, more realistic narrative that is nonetheless symbolic, Don DeLillo's 2007 novel, Falling Man, opens with a third person narrative description of the main character, Bill Lawton, running with the thousands of others as the Twin Towers are falling. Let's follow the opening narrative a few lines:

It was not a street anymore but a world, a time and space of falling ash and near night. He was walking north through rubble and mud and there were people running past holding towels to their faces or jackets over their heads. . .

The roar was still in the air, the buckling rumble of the fall. This WAS the world now. Smoke and ash came rolling down streets and turning corners, busting around corners, seismic tides of smoke, with office paper flashing past, standard sheets with cutting edge, skimming, shipping past, otherworldly things in the morning pall.

...The world was this as well, figures in windows a thousand feet up, dropping into free space, and the stink of fuel fire, and the ready zip of sirens in the air. The noise lay everywhere they ran, stratified sound collecting around them, and he walked away from it and into it at the same time.

And then, in the closing lines of this brief opening chapter, DeLillo tells of a utility truck pulling up alongside Lawton just moments after the second Tower, the North Tower, had collapsed, and he and other survivors had reached a clearing of sorts, where they paused briefly to decide where to flee next:

[T] he driver leaned toward the window on the passenger's side and examined what he saw, a man scaled in ash, in pulverized matter, and asked him where he wanted to go. It wasn't until he got into the truck and shut the door that he understood where he had been going all along. (DeLillo 2007: 3-6 passim.) 
A final example from recent American fiction is the novel Extremely Loud \& Incredibly Close by Jonathan Safran Foer (2005). ${ }^{9}$ Foer, known for his postmodern approach to fiction called 'visual writing' (many of the pages are photos or drawings that mark out themes in the text) makes a nine-year-old boy, Oskar Schell, his protagonist and main narrator. Oskar lives with his parents in an upper-floor apartment building in Manhattan, across the street from his grandmother, whose apartment he can see from his window. As the novel opens two years after 2001, we learn that in the World Trade Center disaster Oskar lost his father, with whom he was very close and interactive in ways that seem quite precocious, for example, his father would present puzzles and mind-twisting treasure hunts that Oskar loved to pursue. The key to understanding his missing father is literally a key that Oskar finds in a vase his father had acquired shortly before $9 / 11$, and the search for what it opens is the last puzzle his father inadvertently left him with to solve. It takes him to dozens of strangers in New York who might possess what his father's key unlocks. We also learn that his paternal grandparents had experienced another disaster in the bombing of Dresden. Extremely Loud \& Incredibly Close deftly shows how unique and personally felt disaster events such as $9 / 11$ and the Dresden bombing were, and yet how interconnected these deep, individual experiences are with other people, even strangers.

Some of the most penetrating creative writing about $9 / 11$ has been by Muslim authors from the Middle East, Pakistan, Bangladesh and India. Their stories of life in the West, particularly America, during the first decade of the twenty-first century make clear that the Muslim-American experience of $9 / 11$ and its aftermath has differed from the Euro-American experience. Arissa Illahi, the protagonist in Shaila Abdullah's 2009 novel, Saffron Dreams, is a hijab-wearing Pakistani woman who has a traditional marriage to Faizan, a young Pakistani man who emigrates to NY in part to pursue a dream to become a writer. Arissa accompanies her new husband to New York where he takes a job as a waiter in the 'Top of the World' restaurant on the uppermost floor of the World Trade Center. He was working on the morning of 9/11 along with 3,000 other employees and visitors from the New York area and around the world. The story opens with Arissa widowed by the collapse of the North Tower; we also learn that she is pregnant with his child who will be born with a rare disease and disability - a personal misfortune which she accepts as a welcome surviving legacy compounded with the disaster visited 
upon thousands of others. Although her Muslim husband was a victim of the September 11 attacks, she is treated as a terrorist by neighbours and strangers alike for no other reason than that she has the same religion as those who piloted the planes into the Twin Towers and that she wears a Muslim head covering. The banner for the book reads: 'You don't know you're a misfit until you are marked as an outcast.' Her story of crossing borders, from traditional Muslim to secular American society, and trying to negotiate her cultural and religious identity in the strange new world of twenty-first century America, reflects the experience of many Muslims living in Europe and America. That 9/11 played a direct role in the fictional life of Arissa Illahi was also true for the many Muslims in real life who lost loved ones in the collapse of the Towers on September 11, or became victims of hate crimes against Muslims, or anyone who looked like they were Muslim, in the immediate social need to blame and punish those perceived to be the enemy. This, too, was a part of the culture of 9/11.

With this background on several ways in which September 11 has had an impact on scholarship, education, personal identity narratives, and the arts and literature, let me move on to pilgrimage and ritual at Ground Zero. What do such terms as 'rite,' 'ritual,' and 'ritualizing' mean in the context of Ground Zero at the site of the collapsed World Trade Center Towers and the thousands of people from around the globe who continue to visit that site?

\section{Defining ritual and the ritualization response}

In 1974, the Chicago historian of religion, Jonathan Z. Smith, delivered a lecture at Pomona College in California, later published under the title 'The Bare Facts of Ritual' (Smith 1982: 53-62). In it he speculated that

ritual represents a controlled environment where the variables (i.e., the accidents) of ordinary life may be displaced precisely because they are felt to be so overwhelmingly present and powerful. Ritual is a means of performing the way things ought to be in conscious tension with the way things are in such a way that this ritualized perfection is recollected in the ordinary, uncontrolled, course of events. (Smith 1982: 63, italics in the original.)

This definition of ritual as a human performance that attempts to address the incongruity of the way things are with the way things ought to be has had considerable influence on historians of religion who specialize in ritual stud- 
ies, including those who are critical of Smith's overall theory of ritual, such as Ronald L. Grimes (1990, 2006b). In Ritual and Its Consequences, Adam B. Seligman (et al. 2000) holds that ritual creates a subjunctive universe. Seligman argues in the same vein as Smith that in ritual we juxtapose a 'what if' world to an 'as is' world. Ritual allows humans to live with ambiguity; it is a way to create coherence out of ambiguity. He offers as an example the rite of grieving for his mother when the Kaddish prayer was recited, in which she was remembered in formulaic fond and loving terms: a perfect daughter, wife, mother and friend. He compared that to the fact of how difficult she had been to live with in many moments of real life. ${ }^{10}$ We ritualize in order to heal and to reorder the disorder of the real world.

For Grimes, 'ritual' is a generic term that denotes 'the general idea of actions characterized by a certain "family" of qualities, for instance, that they are performed, formalized, patterned, and so on' (Grimes 2006b: 163, note 32). For Grimes and many theorists, virtually any behaviour, animal and human, can be ritualized. He defines 'rite' as 'sequences of action rendered special by virtue of their condensation, elevation, or stylization. Rites are distinct, socially recognized set (sic) of procedures. Often they are named as well as enacted, in set-aside times and specially chosen places.' (Grimes 2006: 163.)

Grimes's definition of ritualizing is useful: 'The word "ritualizing” refers to the activity of deliberately cultivating rites.' He distinguishes between 'ritual' and 'ritualizing' by pointing out that the '-izing' ending of the word ritualizing is 'a deliberate attempt to suggest a process, a quality of nascence or emergence. Ritualizing is the act of cultivating or inventing rites'. He makes the further point that ritualizing is not always socially condoned. 'Rather, it happens on the margins; therefore it is alternately stigmatized and eulogized.' (Grimes 1982: 10.) In other words, what we do when we ritualize is often time or place or event specific, such as preparing oneself to enact a suicide bombing, or pausing for a moment of silent prayer when one looks with awe upon the cavity in the ground that once was the imposing World Trade Center complex. Visiting Ground Zero differs from the traditional religious pilgrimages, such as the annual Hajj to Mecca, which local Muslim communities around the world also celebrate in the Feast of the Sacrifice; or the passion play at Easter time, in which Christians around the world can participate through local Easter celebrations. We recognize ritual when we see a priest blessing the 
cup of wine at the altar during the mass, but in our daily routines, we ritualize much more than sacramental and religious rites.

With these definitions as guidelines, we turn now to the consideration of Ground Zero as a site of pilgrimage and ritual.

\section{Ritualizing the attack}

Pilgrimage-like visits to Ground Zero and the ceremonial remembrancesboth religious and secular-began as spontaneous forms of ritualized behaviour, and they began almost immediately after September 11, although for several weeks the mourners and visitors were not allowed to approach Ground Zero itself, for health, safety and security reasons.

As suggested above, however, one must back up a year, perhaps even longer, to begin to comprehend the rituals and ritualized behaviour that led to $9 / 11$. The scholar of ritual must recognize the ritualized behaviour of the 19 hijackers who sought martyrdom in the event of $9 / 11$. Although the information on what transpired during the months the hijackers were preparing and being prepared for their task is still rather sparse, two versions of the text exist that guided them through purity rites, prayers and psychological preparation from the night of September 10 through the next morning up to boarding the plane and taking command of it. The text has deep resonances with Muslim rituals of bodily cleansing, prayer and animal sacrifice despite the sharp incongruity of the attack on the World Trade Center with the normative performance of Muslim rites of purification, prayer and sacrifice.

It will no doubt seem perverse to some people to link the rites of those who carried out the attack at the World Trade Center with the rites of those who survived and were memorialized at Ground Zero. Nonetheless, the scope of my topic-pilgrimage and ritualizing at Ground Zero-necessarily includes the rituals that brought 19 young Muslim martyrs to their death along with the victims in the three planes and those who perished at the World Trade Center, the Pentagon, and in the third plane that crashed in a field in Pennsylvania (falling short of its intended target-probably the White House or the Capital Building in Washington, DC). The relationship of rites of martyrs and victims exemplifies what philosopher Charles Taylor, in another context, refers to as an internal dyad - a pair of elements in relational opposition: up implies down, inside implies an outside (Taylor 2009: $1144 \mathrm{ff}$.). Thus, Taylor explains, in pre-modern times (in European and Western societies) the religious dimension of life was comprehended in terms of its opposite-the world, the 
secular-and vice versa. In modern times, Taylor avers, the secular can be comprehended on its own without reference to the religious; the religious and the secular have become, in modern times, an external dyad; they have lost their religious reciprocity.

The dyadic relationship is often cited in social science analyses. The relationship of martyrs to victims on September 11 can be construed as an internal dyadic relationship. That neither martyrs nor victims knew personally nor wanted to know each other, does not negate the necessary relation of each to the other. For the purposes of ritual analysis, suicide martyrs and their victims should be treated as existing in an internal dyadic relationship. Exploration of the reciprocal ritual relationship between attackers and victims, symbolized by Ground Zero, lies beyond the scope of this article; however, it is a topic that invites further reflection and analysis. The analysis in this article continues with a brief consideration of the ritualizing dimensions expressed in the documents that guided the hijackers through the last few hours as they prepared for September 11.

\section{Ritualizing at Ground Zero}

Religious, and indeed ritual, preparation for war and for violence against enemies is well established in the history of religions. ${ }^{11}$ In the Book of Joshua in the Hebrew Bible, Joshua is commanded by God to prepare flint knives and to make the Israelites a circumcised people again in readiness for the conquest of Canaan (Joshua 5:2). The enemies of the Israelites (and the Lord) are regarded as vulnerable to attack because the God of the Israelites is on their side (see Harris et al. 2000: 40 ff.; see also Aho 1981). More recently during the war in Iraq, there have been several reports of prayer and other modes of religious preparation and construal of the war in a Christian evangelical framework. Such was the case, but with reference to Muslim ritual behaviour, also for the martyr-attackers on September 11, 2001.

In his preface to one of the more insightful studies of 9/11, University of Chicago historian of religion, Bruce Lincoln, states:

[T] he most pressing item [for the scholar] to ponder was the extent to which the attacks of September 11 could be considered religious. My ini- 
tial attempt involved a close reading of four key texts: the instructions that Muhammad Atta and others studied the last days of their lives..., speeches given by George W. Bush and Osama bin Laden as military action commenced in Afghanistan on October 7..., and the interpretations of September 11 offered by Jerry Falwell and Pat Robertson immediately thereafter. . (Lincoln 2003: ix.) $)^{12}$

In his analysis of the English language translation of Muhammad Atta's instructions and preparations for 9/11 found in personal belongings he left in his car in Boston, Lincoln points out that this text, which guided the hijacker/ martyrs the last hours before the end, curiously makes only vague allusions to the actual target and the result they will bring about. It is a strange and surreal text. An anonymous author, who is never identified, guides them in the performances they will enact to attain martyrdom. Specifics, such as the passengers to be killed on the plane and in the World Trade Center and Pentagon are only alluded to; it is a document that stresses purity, prayer and ritual acts. The instructions begin with an invocation to God. ${ }^{13}$ Next follows a section called 'The Last Night', in which the hijacker/martyrs are instructed to purify their bodies by removing excess body hair, bathing, and applying cologne. Then, the soon-to-be martyrs are told the last night is a time for spiritual preparation, Qur'an reading and reflection, and to review their task ahead on the next day. The 'Second Step' jumps forward to the following morning-getting to the airport and through the airport, its checks, securities, and secular spaces. The anonymous author of the document admonishes the hijackers to keep their concentration as they make their way through the airport by constantly saying appropriate prayers and supplications. Toward the end of the document, the young men are admonished: 'Do not seem confused or show signs of nervous tension. Be happy, optimistic, calm, because you are heading for a deed that God loves and will accept. It will be the day, God willing, you

12 The Robertson broadcast was aired on the Christian Broadcasting Network program '70o Club' on September 13; see http://www.youtube.com/watch?v=H-CAcdta_8I (last viewed on 11 January 2010).

13 The papers identified as the instructions to the hijackers in preparing for and carrying out their martyrdom September 11, 2001 (found in the personal remains of two hijackers but perhaps originally in the possession of all of them) apparently in Muhammad Atta's case was a compilation of the header page of his last will and testament (a statement to family and friends when preparing for death) and the main body of the instructions for the 9/11 event. See Campo 2003. 
spend with the women of paradise.' ( $\$ 24$ in the translation cited by Lincoln in Appendix A.)

The section labelled 'The Third and Final Phase' covers boarding the plane and what must be done in it. One is to enter the plane with prayer and supplication and remain in a prayerful state until the plane takes off. It then refers to the moment in the air when the 'two groups' come together, referring to those who will pilot the plane and those who will take physical control of the passengers and crew in the main cabin. Throughout the instructions the events of that fateful day are compared to and interpreted by reference to well-known events in the life of the Prophet as he fought to establish his religion in Mecca and Medina. Those they are attacking are likened to infidels and backsliders and followers of Satan; their world-the world of the victims-is also likened to the time of Jahilyyah (the time of moral and spiritual ignorance before the Prophet came).

The hijacker/martyrs were instructed and trained to participate in what is clearly a ritualized event. It was not a set of ordinary instructions such as, 'go to the end of the block, then turn left to the traffic light, then look for a tall building, etc. . . ' All throughout the document are calls for preparations of ritual purity, strategically placed Qur'an citations, allusions to the time of the Prophet Muhammad, and prayers and supplications that every Muslim would recognize. However, the attack on the World Trade Center was not a canonical Islamic rite, such as the 'Id of the Sacrifice, celebrated during the Hajj pilgrimage to Mecca. It was the sort of rite that Grimes identified above as a performance on the margins, liable from different points of view to be 'stigmatized or eulogized', depending on one's moral, cultural and religious horizon of understanding. 9/11 has the guise of orthodox Muslim ritualization. Yet the overwhelming majority of Muslims do not accept, indeed firmly reject, the mission on which these young men were sent as an Islamic duty or divinely sanctioned deed. It was a concatenation of familiar ritual elements to effect what, from an orthodox Islamic point of view, was a most unfamiliar and terrible result. Many would protest that the complex of activities the hijacker-martyrs performed was not Islamic, indeed, the antithesis of Islam. However, the historian of religion cannot but recognize the performances of the hijacker-martyrs as religious as well as the ritual elements in their performances. 


\section{Pilgrimage and ritualization at Ground Zero}

In June of 2002, I had my first glimpse of Ground Zero, the site of the devastation of the World Trade Center in New York just nine months previously. I was there with my 16-year-old daughter for what had become for us an annual pilgrimage to New York each year after school was out, to visit museums and enjoy New York. The total destruction of the two giant towers and of everyone left in them when the buildings collapsed was still being cleared away. A fence had been hastily erected around the site. Across the street from the fenced-off ruination, the sidewalk was jammed with a jumble of hastily assembled mementos, photos of the missing, American flags, models of the Twin Towers, t-shirts and baseball caps of the NYFD and NYPD commemorating the firemen and policemen who had lost their lives on September 11. Relatives and loved ones had left photos and remembrances of the dead, and vendors were retailing kitsch—cheap and gaudy mementos of the event of 9/11.

The scene reminded me of visits to saints' shrines and tombs in Egypt and Pakistan. There, too, one finds kitsch-sacred and secular-for sale by vendors as well as gifts and remembrances left by pilgrims and tourists for the saint whose relics sanctify the shrine. Along with Qurans, hagiographies of the saint(s) enshrined in the mosque, Quranic calligraphy on wall hangings, and posters of the ninety-nine beautiful names of God were miniature stuffed Santa Clauses and dolls, posters of famous actors, and the like in a sacred/ secular brew of souvenirs for pilgrims and tourists coming to the site.

So much at Ground Zero seems familiar to the historian of religions: The solemn throngs of visitors undifferentiated as to social rank by religious, racial, and national identities; the ceremonies of remembrance on the anniversary of September 11; the sacred remembrances left and souvenirs purchased. This much bespeaks of pilgrimage and what Muslims know as ziyara, or visiting the shrines of saints. Yet such a comparison seems far-fetched. The World Trade Center had been the site of global trade and finance, not religion or religious activities. It had been a place drenched in the secular concerns of Wall Street. Most of the visitors were clad in the clothing of modern tourists-blue jeans, short pants and t-shirts and blouses; they did not remove their shoes, or even their baseball caps and hats. Except for the occasional clerical collars of priests and the habits of nuns, or the turbans of Asian Hindus, Sikhs and Muslims, no religious or special vestments or attire was worn.

No organized special activities mark off the visit to Ground Zero from other tourist and public gatherings in New York, such as at Times Square. In a strict sense of religious pilgrimage, Ground Zero was and is not a pilgrimage 
site; visiting Ground Zero is not a pilgrimage performance, in the same sense that going on Hajj to Mecca, or following the Via Dolorosa in Jerusalem, or the stations traversed by Buddhist pilgrims in Shikoku and Saikoku, Japanto name just three of scores of religious pilgrimage sites that continue to draw visitors in modern times. Nonetheless, visiting Ground Zero is not exactly not a modern pilgrimage. The observer does notice a certain aura of reverence and awe, especially in the early years following 9/11, among those who came to pray, ponder, and peregrinate around among the souvenirs and posters that surrounded the empty pit that once was the site of the Twin Towers.

The religious rituals that were generated in response to $9 / 11$ and the smoking, hoary aftermath of the attack at Ground Zero with its pall of death and absence were far less durable and perennial than the stuff that structures the well-known pilgrimages in most world religions. Nonetheless, ritual is found in the images that surrounded 9/11, much of it on the Internet and in performances of clergy and poets and firemen who confronted Ground Zero directly in the awful moments that immediately followed the attacks. Many visitors who came later to stand at Ground Zero and reflect on the immensity of what had happened no doubt had struggled with the image of what the victims had had to do, for example, confront the vertiginous dread of having to have jumped from above the 86th floor-into what? Was it simply a desperate nihilistic act? Yet many have noticed that often the divers reached out and held hands-reaching out to link with the palpable humanity in the hand of a friend or a little-known office colleague. Perhaps many visitors had read, heard, or heard about the last messages sent to loved ones from passengers on the doomed aircraft once they knew their fate. Those images did generate ritualized responses to 9/11 and Ground Zero. Those and other images like them dominated my mind when I first stood at Ground Zero in the late spring of 2002, and I suspect they have for the tens of thousands of pilgrim-visitors who have stood and silently mingled there since. I will close with brief descriptions of two ritualized responses to 9/11 and Ground Zero that are quite moving. Both were captured on video and narrated on the Frontline production of 'Faith and Doubt at Ground Zero.' ${ }^{4}$

The Remains. The atomized remains of the victims in Twin Towers of the World Trade Center did not amount to much, but those small pieces of human bodies and artefacts were deeply significant, to family and friends, as well as

14 From the transcript of the television production, found at http://www.pbs.org/wgbh/ pages/frontline/shows/faith/etc/script.html (viewed on 17 January 2010). 
to the rescue workers and firemen who worked to clear Ground Zero in the days, weeks and months following $9 / 11$. The removal process was structured by first being careful to find human remains, long after any hope of finding anyone alive was past. What kind of funerary rites would be appropriate in conditions where the identity of the victim could not be immediately determined from a minute piece of flesh and when DNA testing would take days or weeks? New York photographer Joel Meyerowitz was struck by the task of removal that fell to rescue workers, prying day after day through the rubble to find and remove the gruesome remains of the victims. He describes what he saw one day when he visited ground Zero:

I was down there at a moment that they were finding a larger number of remains. And coming up the ranks were six firemen carrying a little sled, draped with a flag. Every single person took off their helmet, put it over their heart, saluted, did this traditional American gesture of respect for the dead, and there was no one to do it for. There was no press. It wasn't a public demonstration. It was for the dead. And they did it over and over again.

But that weighs on them. That-it's a reminder because they have to put that - that remains on that sled. They have to handle that. And some of the remains are beyond words. (Transcript, Act Five, 'Ground Zero'.)

Litany of Love. Conservative New York rabbi Irwin Kula was deeply touched by the poetry, the simple statements of love and human connectedness expressed in last statements on cell phones from victims on the airplanes hurtling toward their fates. Commenting on what $9 / 11$ evoked in his religious consciousness, he spoke candidly:

My genuine experience of life is that there is nothing out there, this is all there is. And when you see the seamlessness of it all, that's what I mean by God. Every tradition has that. Every morning, three times a day since I'm 6 years old, 5 years old, I've been saying, 'Hear O Israel, the Lord our God, the Lord is one.' Right? It's one of our few creedal statements, right, the Shema. Three times a day since I'm 6 years old.

And $9 / 11$, I guess - if you ask me what did $9 / 11$ really do, it made me understand the truth of that, that the truth of that, everything is one. Not that there's some guy hanging out there who has it all together, who we call One, but that it is all one. 
We all know it deep down! We've all had those experiences, whether it's looking at our child in a crib, or whether it's looking at our lover or looking at a mountaintop or looking at a sunset, right? We've all had those experiences when we recognize, 'Whoa! We're much more connected here.' That's what those firemen had. They recognized. Now, they didn't have time to think about it, right, because actually, if you think about it, you begin to create separations. They didn't think about it. All they knew was we're absolutely connected. We're absolutely connected to the 86th floor.

For Rabbi Kula, the litany form of the chanting ancient sacred text is reapplied to the modern texts of cell phone last expressions of impending death and last good byes to loved ones:

Rabbi Brian Kula: [Singing-(in the manner of a rabbinical chant)] Hey, Jules. It's Brian. I'm on the plane and it's hijacked, and it doesn't look good. I just wanted to let you know that I love you and I hope to see you again.

[Commenting] These are final conversations that were recorded on cell phones, recorded on voicemail. They're so pure about the expression of love between husband and wife, between mother and child. They seem to me to be incredible texts because they were at the moment of confronting life or death. And for me, I chant these every single morning because they remind me that whatever my tradition is about, it's about this.

[Singing] Mommy, the building is on fire. There's smoke coming through the walls. I can't breathe. I love you, Mommy. Goodbye.

[Commenting] The real Torah, the real wisdom, the real religious tradition, the real experience behind religion, is about love and is about connection and is no more complicated than that.

[Singing] Honey, something terrible is happening. I don't think I'm going to make it. I love you. Take care of the children. (Transcript, Act 2, 'The Face of God'.)

These final examples of ritualization at Ground Zero, and there are many others, are isolated and do not quite form a structured pattern recognizable to the historian of religion as a pilgrimage. They do not amount to a durable 
tradition of performance that marks visits to the site of the former World Trade Center as a pilgrimage qua religious pilgrimage. Yet the place and the event that Ground Zero evokes and symbolizes have drawn people from far and wide to that site for over seven years at the time of this writing. Ritualized behaviour at Ground Zero is in response to a disaster of huger proportions for most Americans and others. Ground Zero was a place that had to be ritualized. The story of that process may have a shelf life, but it seems to be far from over. What people have done at Ground Zero in response to 9/11 needs to be observed and analyzed by historians of religions and scholars of ritual studies, as well as novelists, artists, and all thoughtful people living in the twenty-first century.

\section{References}

\section{Abdullah, Shaila}

2009 Saffron Dreams. Ann Arbor, MI: Modern History Press.

\section{Aho, James A.}

1981 Religious Mythology and the Art of War: Comparative Religious Symbolism of Military Violence. Westport, CN: Greenwood Press.

\section{Bilgrami, Akeel}

2003 The Clash Within Civilizations. Daedalus 132: 88-93.

\section{Campo, Juan}

2003 Review of Bruce Lincoln's Holy Terrors. The University of California website eScholarship November 1, 2003. http://www.escholarship.org/uc/item/ 93W597c9 (accessed on 17 January 2009).

\section{DeLillo, Don}

2007 Falling Man. New York: Scribner.

\section{Foer, Jonathan Safran}

2005 Extremely Loud \& Incredibly Close I. London: Penguin Books.

Grimes, Ronald L.

1990 Ritual Criticism: Case Studies in Its Practice, Essays on Its Theory. Columbia, SC: University of South Carolina Press.

2006a Ritualizing September 11. In: Ronald L. Grimes, Rite Out of Place: Ritual, Media and the Arts; pp. 73-86. Oxford: Oxford University Press.

2006b Rite Out of Place: Ritual, Media and the Arts. Oxford: Oxford University Press.

Harris, J. Gordon et al.

2000 The Religious Preparation for War. In: J. Gordon et al., Joshua, Judges, Ruth; pp. 40 ff. Peabody, MA: Hendrickson Publishers. 


\section{Huntington, Samuel P.}

1993 The Clash of Civilizations? Foreign Affairs 72 (3): 22-49.

1996 The Clash of Civilizations and the Remaking of World Order. New York: Simon \& Schuster.

\section{Kamil, Jill}

2000 Religious Tourism as Big Business. Al-Ahram Weekly On-line (17-23 2000, no. 469). http://www.stmina-monastery.org/stmenas_ahramweekly469.pdf (accessed on 20 October 2009).

\section{Lincoln, Bruce}

2003 Holy Terrors: Thinking about Religion after September 11. Chicago \& London: University of Chicago Press.

\section{Martin, Richard C.}

1996 Islamic Studies: A History of Religions Perspective. Upper Saddle River, NJ: Prentice-Hall.

\section{Mosley, Nicholas}

2003 Inventing God. Urbana \& Champaign, ILL: Dalkey Archive Press.

Post, $\mathbf{P}($ aul $)$ et al.

2003 Disaster Ritual: Explorations of an Emerging Ritual Repertoire. Louvain, Belgium: Peeters Publishers.

\section{Schleiermacher, Friedrich}

1799 Über die Religion: Reden an die Gebildeten unter ihren Verächtern. Göttingen: Vandenhoeck \& Ruprecht. (In English: On Religion: Speeches to Its Cultured Despisers, trans. by John Oman. Louisville, KY: John Knox Press, 1994.)

Seligman, Adam B. et al.

2000 Ritual and Its Consequences: An Essay on the Limits of Sincerity. Oxford: Oxford University Press.

Smith, Jonathan Z.

1982 Imagining Religion: From Babylon to Jonestown. Chicago: University of Chicago Press.

\section{Taylor, Charles}

2009 'The Polysemy of the Secular'. The Religious/Secular Divide: The U.S. Case. Social Researchj: An International Quarterly 76 (4): 1143-66. 